\title{
Elaboration on Public Administration Crises: An Endeavor in Seeking Scientific Identity
}

\author{
Iwan Tanjung Sutarna ${ }^{1}$ \\ Khuriyatul Husna ${ }^{2}$ \\ Paramita Iswari ${ }^{3}$
}

\begin{abstract}
This paper aims to elaborate the crises occurring in the science of public administration based on significant conceptions of scholars. Public administration's initial emergence as a novel scientific discipline sparked a theoretical-conceptual debate specifically in the domain of epistemology. For the sake of systematical order, this paper is divided into three phases of crisis based on the dynamics of the theoretical-conceptual development of public administration, namely: (1) identity crisis; (2) paradigm crisis; and (3) intellectual crisis. The illustration of each crisis phase is aimed at conveying conception points of scientists which facilitates in reading the narrative of shifts and theoretical-conceptual contents including their inherent values. For this reason, a search or walkthrough of relevant literature is necessary to observe the development of thoughts in public administration. The study result shows that the differing ideas and argumentations which had occurred throughout every discussion on public administration have had implications on the heterogeneity of the public administration field. The various shifts of locus-focus and paradigm in public administration is seen as a systematic attempt in finding its true self as a scientific discipline. The efforts of public administration in separating itself from the shadows of political science was also observed, although being capable of truly separating itself is considered as extremely difficult, bearing in mind that the focus and locus of public administration is very much affected by constantly developing social political influences. In addition to that, various shifts of locus and focus seems to have empirical implications particularly in the scientific scope of public administration.
\end{abstract}

\section{Keywords:}

crisis; identity; paradigm; intellectual; public administration.

\begin{abstract}
Abstrak
Makalah ini bertujuan melakukan elaborasi terhadap krisis pada disiplin Ilmu Administrasi Publik, berdasarkan pemikiran penting para ilmuwan. Di awali kemunculannya sebagai disiplin ilmu baru yang mampu memantik perdebatan teoritik-konseptual khususnya pada ranah epistemologi. Sebagai upaya sistematis, paper ini akan dibagi berdasarkan dinamika perkembangan teoritik-konseptual ilmu administrasi publik ke dalam tiga fase krisis yaitu: (1) krisis identitas; (2) krisis paradigma, dan; (3) krisis intelektual. Penggambaran masing-masing fase krisis bertujuan untuk menyampaikan poin-poin pemikiran para ilmuwan sehingga memudahkan membaca alur pergeseran-pergeseran dan muatan teoritik-konseptual termasuk nilai yang menyertainya. Sehingga penelusuran literatur terkait diperlukan untuk melihat gambaran perkembangan pemikiran ilmu administrasi publik. Hasil menunjukkan perbedaan ide dan
\end{abstract}

\footnotetext{
${ }^{1}$ Faculty of Social and Political Sciences Muhammadiyah University, Mataram

Email : iwantanjungsutarna1984@gmail.com

${ }^{2}$ Faculty of Administrative Science Lancang Kuning University, Pekanbaru

${ }^{3}$ Chairperson of Perhimpunan Lingkar Pembaruan Desa dan Agraria (KARSA)
} 
argumentasi yang terjadi dalam setiap pembahasan administrasi publik berimplikasi terhadap heterogenitas di dalam field of public administration. Berbagai pergeseran lokus-fokus, paradigma dalam adminsitrasi publik terlihat sebagai upaya sistematis menemukan jati dirinya sebagaisuatudisiplin. Terlepasdaribayangbayang itmupolitik, meskipun upaya untukbenar-benar terpisah tampaknya menjadisuatu hal yang sangat sulit, mengingat lokus dan fokus Ilmu administrasi Publiksangatdipengaruhiolehpengaruh sosial-politik yang terus berkembang. Tidak hanya itu saja, berbagai pergeseran lokus dan fokus tampaknya memiliki implikasi empiris khususnya dalam ruang lingkup keilmuan administrasi publik.

\section{Kata Kunci:}

krisis; identitas; paradigma; intelektual; administrasi publik.

\section{Introduction}

The advent of administrative science as a novel scientific discipline is undoubtedly inseparable from the influence of Woodrow Wilson. Wilson is a political science professor who wrote the essay under the title "The Study ofAdministration". The publication of this essay was an effort in responding to problems of the US administration which was undergoing an abnormal phase and was undertaking civil service reform. Woodrow Wilson through his seminal article proposed an idea in the importance of establishing a new scientific discipline named administrative science. Wilson believed that administrative science can be utilized as a new approach possessing the capacity to assist the government in breaking away from the crisis.

Woodrow Wilson's emphasis was placed on the systematic effort of separating administrative and political authorities. Politics is considered to be identical to making decisions whilst administration to executing decisions. This argument is then known as the politics-administration dichotomy. Woodrow Wilson's essay became the trigger for other scientists to propose various theoreticalconceptual ideas. J. Frank Goodnow was one of the scientists who subsequently reaffirmed Woodrow Wilson's theoretical-conceptual argumentation regarding the importance in separating politics and administration. Frank Goodnow stated that the importance in the limitation of politics-administration institutional function is resolutely based on the authority it wields. The ideas proposed by Woodrow Wilson and Frank Goodnow had consequently induced a debate on the identity of administrative science as a new scientific discipline, resulting in the question whether it is feasible for it to be considered as science or not. Other scholars such as Simon and Waldo also contributed to enrich the identity crisis phase of administrative science by stressing the importance of scientific principles and values in the study of administration.

Subsequently, the paradigm crisis in public administration study is discussed. Debates pertaining to paradigm remain an unfinished topic of discussion as of current. Bearing in mind the highly astute perspective of experts, as a scientific discipline, public administration is not regarded to have a single paradigm considering its multidisciplinary nature. This point of view refers to Kuhn's concept of paradigm, as well as the theoretical arguments of Nicholas Henry and Norma M. Ricucci. Following the discussion on paradigm crisis, this paper will provide an illustration on the dynamics surrounding the intellectual crisis by referring to the ideas of Vincent Ostrom and Shamsul Haque. The ideas of Shamsul Haque in the article titled "The Intellectual Crisis in Public Administration in The Current Epoch of Privatization" is of particular interest to be discussed regarding its criticism on the implementation of market (privatization) values on the public sector. 


\section{Research Method}

In order to understand the development of public administration along with the crises it has endured, a literature study utilizing primary and secondary sources was employed in this study. The information acquired from primary and secondary sources were those referring to study results, articles, and journals relevant to the development of public administration conducted directly through original literature (writer) search. As for secondary sources, they were obtained from review results of other writers or original documents often referenced in studying public administration, along with encyclopedias, dictionaries, handbooks, abstracts, indices, and textbooks.

\section{Result and Discussion}

\section{Elaboration on Public Administration Crises: An Endeavor in Seeking Scientific Identity}

The theoretical-conceptual debate on administrative science began with the publication of Woodrow Wilson's essay titled "The Study of Administration". Its publication sparked a debate on the essence of administrative science. How could it not, Wilson clearly stated the importance of studying administrative science in higher education institutions as an effort in finding means of achieving success and carrying out proper conducts by considering aspects of efficiency (Wilson, 1887: 197).

In the context of administrative science as a new scientific discipline, Woodrow Wilson palpably conveyed that administrative science is a derivative of political science by saying that "the science of administration is the latest fruit of that study of the science of politics which was begun some twenty-two hundred years ago" (Wilson, 1887:198). To Wilson, the advent of administrative science can assist the government in finding ways of improving itself, enhancing performance and strengthening the organization, and being mindful of the emphasis in the aspect of efficiency which serves as Wilson's point of departure. Particularly due to the fact that America at the time was undergoing civil service reform under abnormal governmental conditions; confusion, disorientation, corruption, and other bad practices which poorly impacted the administration. For that reason, an approach capable of addressing these various conditions was necessary, as asserted in Wilson's seminal essay.

"Thisis why there should bea science ofadministrationwhich shall seek to straighten the paths of government, to make its business less unbusiness like, to strengthen and purify its organization, and to crown its duties withdutifulness. This is one reason why there is such a science" (Wilson, 1887: 201).

Upon careful observation of the above argumentation, the administrative science proposed by Wilson is indeed constructed as a science that is different to political science. Administration is outside the scope of politics (Wilson, 1887:210). This argument was undeniably intended to be a systematic effort in restricting the administrative and political scopes. The idea was definitely inseparable from several changes happening in the American public sector during that period. The reality at the time became a dominant factor for Woodrow Wilson to contribute in improving the disorientation of government administration in the US. The idea subsequently signified the initial period in the emergence of the politics-administration dichotomy. Politics focuses on objects such as politics, government, and public (policy) decision making. As for administration, it pertains to the function of carrying out political decisions by emphasizing the institutional aspect of bureaucracy as the implementer.

The theoretical-conceptual argumentation of Woodrow Wilson eventually acquired the 
support of other scientists such as Frank J. Goodnow. Through Goodnow's book under the title Politics and Administration: A Study in Government, he stated the importance of separating administrative and political authority. Goodnow's idea may at a glance seem like the theory of trias politica coined by Montesquieu, i.e. the separation of the legislative, executive, and judicial authorities. However, Goodnow emphasized the aspect of administrative and political authorities.

Goodnow asserted that there are three authorities responsible for carrying out the state's will: (1) judicial authority; (2) executive authority; and (3) administrative authority (Goodnow, 1900: 17). In this context, Goodnow stressed the aspect of the executive and administrative authorities. Upon further study, the executive authority is said to lay emphasis on the political (state will policy) dimension, whilst the administrative authority underlines the policy executor dimension; wherein bureaucracy serves as the locus of administration. In other words, politics pertains to policies or expressions of the state's will, and administration refers to execution of state policies (Wilson, 1887: 2010; Goodnow, 1900: 18). In line to the above, Leonard D. White, a Chicago University political scientist, also argued that politics should not influence administration. Although there was a systematical effort in restricting the politics-administration scopes, this initial period had not clearly asserted that public administration study is separate from political science. Luther Gullick is of the same opinion, in which he considered public administration to be a part of political science (see Hiba Khodr, 2005: 6-7).

Wilson and Goodnow's academic conception regarding the dichotomy of politics and administration continued with the rise in the debate of whether public administration is a science or art (Riccuci, 2010: 6-9). This debate is signified with the exchange of opinions carried out by two scholars who greatly contributed to the development of public administration, namely Herbert Simon and Dwight Waldo (Riccuci, 2010: 23). Their debate did not only deepen the identity crisis of public administration, but it immensely contributed to the epistemological domain of public administration as well. Herbert Simon criticized that if public administration wanted to be regarded as a science, then it should have a measuring tool that is objective and value free. Meanwhile, Dwight Waldo claimed that it is impossible for public administration to be free of values, particularly since public administration deals with "humans". When dealing with human sensibility, it is consequently impossible for public administration to adhere to the idea proposed by Herbert Simon.

Administrative Behavior by Herbert Simon (1947) marked the beginning of a new critical movement or direction in the field of public administration, especially from the perspective of study or theory. Wilson's conception had proposed the notion of politics and administration dichotomy in which the administration holds the value of efficiency. It is this very value of efficiency which served as Simon's reference in viewing efficiency objectively by conducting experiments and empirical research, wherein public administration study should be based on facts that are empirically derived, measured, and verified.

Herbert Simon criticized the approach of the orthodox theory, as in his view, public administration must be observed from the perspective of scientific principles when employed in social sciences. The contradiction conveyed by Herbert Simon ignited an on-going discussion particularly in the methodological domain. Simon stated that there is a basic contradiction to separate "legislator and administrator" especially in validating the aspect of value in decision making (see Kent, 1977: 325). According to Herbert Simon, if administrative science were to be placed as 
a scientific discipline, then a measurement that is objective and value free is of necessity. Simon's idea caused an epistemological debate in public administration and brought in administrative science to becoming familiar with the positivistic approach. From a science perspective, Herbert Simon's conception has contributed significantly to the development of public administration's theory and research methodology (see Riccucci, 2010: 8-9).

Simon's idea subsequently received strong criticism from Dwight Waldo - an American scientist who have contributed much to the development of administrative science. According to Dwight Waldo, it is difficult to apply the value free claim as intended by Herbert Simon. Public administration, as is the case of other social sciences, pertains to humans inherent with the characters of reasoning, feeling, and evaluating. Waldo, through the Minnowbrook Conference, attempted to shift the locus of public administration from efficiency towards social justice. This concurrently attacked the idea of value free and marked the return in establishing value, ethics, and morality as the idea of New Public Administration (NPA) (see, Riccucci, 2010: 11-14).

Eventually, Dwight Waldo appreciated what had been done by Herbert Simon which is asserting that in certain issues, objectivity in public administration is necessary. Nevertheless, this is not universally applicable, because it is highly impossible to separate people and politics from values, ethics, and morality, hence it is unreasonable for public administration to be studied objectively (Result of Minowbrook Conference 1968, in Riccuci, 2010).

The Simon-Waldo debate is also interesting to be observed as a pivotal note in public administration's identity crisis. This is rightly so because questions regarding whether public administration is an art or science subsequently became an on-going debate involving other scholars. In order to address this question, a three group division was employed. The first group asserts that public administration is a science by applying a positivist approach. The second group states that public administration is an art by emphasizing on the aspect of value, wherein this approach is a representative referral to New Public Administration (NPA). As for the third group, they declare that public administration is both science and art, wherein they lay emphasis on the importance of pluralistic approach in public administration study (see Riccucci, 2010: 16-18).

The identity crisis experienced by public administration is unquestionably not unconnected to the vague definition of publicness itself (Pesch, 2005: 7). Udo Pesch attempted to elaborate on a number of publicness definitions with the hope that it could become one of the solutions for public administration's experience with identity crisis. As conveyed by Lan and Anders, publicness is identified as public administration's paradigm because it differs with the focus and locus of private organizations (see Riccucci, 2010: 24-26). Thus, it is important to provide elaboration on the paradigm crisis of public administration in the following section with the aim of capturing the complexities of each crisis, particularly in obtaining an overall narration of the great debates among scholars.

\section{Paradigm Crisis}

The paradigm debate in public administration cannot be removed from a scholar by the name of Thomas Kuhn. Although Kuhn had a background as a physicist, he had provided substantial contribution to the development of thoughts in social science disciplines. His academic contribution which impacted social sciences pertains to the model of scientific revolutions which is eventually known as paradigm. Regarding the word "paradigm", Thomas Kuhn (1962) in Riccuci (2010: 21) stated that a paradigm is a theoretical framework and that "a paradigm is essential to scientific inquiry and progress". It is a framework which can be 
used for scientific investigation and for the advancement of a scientific discipline especially in establishing academic consensus. According to Kuhn, the paradigm development model consists of several stages: Paradigm I $\rightarrow$ Normal Science $\rightarrow$ Anomalies $\rightarrow$ Crisis $\rightarrow$ Revolution $\rightarrow$ Paradigm II. In his opinion, scientific revolution undergoes these four stages, and it will go through a period of revolution in order to supersede the previous paradigm. Normal Science is a period of knowledge accumulation, wherein scientists work on and develop an influential paradigm. In the process of developing paradigm there is an unavoidable anomaly that will ultimately reach a point of crisis indicated with the declining validity of the initial paradigm thereby requiring a new paradigm to resolve it. Paradigm is a key terminology in the scientific development model introduced by Thomas Kuhn (see, Ritzer, 2013:4). Scientific development does not occur accumulatively but during a certain period through a revolution. The term paradigm refers to a model which governs scientific investigation of a scientific discipline within a certain period of time. This is why, "something" is determined to be considered as a paradigm if a joint commitment were reached in the community of relevant scientists regarding the aspects of theoretical, epistemological, and methodological constructions of a scientific discipline (see Riccucci, 2010:22).

It is interesting to see the result of Thomas Kuhn's research on whether a particular science has a paradigm or not. The research result Kuhn acquired regarding a theory presented by two different scientists under varying situations and time, was that they were actually not mutually connected. Therefore, in a paradigm shift, there is no connection between one paradigm and another. The study conducted by Kuhn resulted in a statement that if a science had a paradigm, then there is no connection/ relation between one paradigm and another. The new paradigm supersedes the previous one which subsequently will not be used anymore. What about public administration? This is the big question that often sparks never ending debates in public administration, particularly in the epistemological domain. Each scholar has different approaches which would then fill up discourse spaces and impels debates without end to continue emerging up till today.

Referring to the above argument, the big question regarding paradigm that we can ask is: does public administration have a paradigm? Keeping in mind that the position of public administration in the identity crisis conception dialog discussed in the previous section remains far from over. It is unquestionably difficult to find absolute truth that applies universally as is found in natural sciences. Particularly when human is positioned as a subject matter.

Rainey (1994) states that public administration has no paradigm. His argument is that public administration is an applied science which applies scientific knowledge to address practical matters. Rainey's opinion is strengthened with the argument that public administration study does not have a paradigm due to its multidisciplinary scientific character, as it is influenced by studies in politics, law, sociology, and economy. In other words, public administration utilizes the approaches of other scientific disciplines as its body of knowledge. Lan and Anders (2000) then states that publicness serves as public administration's paradigm. Their argument is by considering to what extent does public authority affect or influence organizations; differentiating between public and private organizations; differentiating between public and private management (see Riccucci, 2010:24-26).

The opinion of Udo Pesch is also of interest to be observed in order to strengthen the argument proposed by Lan and Anders. Udo Pesch states that the essence of public administration is in combining the two definitions of publicness. The first refers to the production of goods and services, while 
the second states that administration acts in response to public interest in the form of laws and policies (Udo Pesch, 2005:187).

A more complex opinion on the paradigm of public administration can be found in the writing of Nicholas Henry, a professor of Georgia University who wrote an article under the title "Paradigms of Public Administration". Nicholas Henry divided public administration paradigms into five stages of paradigm as explained in the following:

\section{Paradigm I: Politics-Administration Dichotomy, 1900-1926}

Goodnow and Leonard D. White's thoughts marked the phase of politicsadministration dichotomy. Although the theoretical-conceptual ideas they conveyed were not more than a systematical effort in reinforcing what has been stated by Wilson in the initial phase of public administration's rise as a scientific discipline.

Politics, Goodnow stated, refers to policies or expressions of the state's will, while administration refers to the execution of said policies. This is no different to the emphasis point of paradigm one, regarding the locus of public administration. Goodnow firmly asserted that government bureaucracy is the locus of public administration. The politics and administration dichotomy is also a basis for Leonard D. White (1926) in his work titled Introduction to Study of Public Administration in which it is stated that public administration is able of becoming a value free science. This is because there is separation between politics and administration, with its point of emphasis on efficiency (see Nicholas Henry, 1975:379).

\section{Paradigm II: Administration Principles, 1927- 1937.}

This paradigm began from a book written by W. Willoughby under the title Principles of Public Administration in 1927. The book indicated new belief in public administration wherein scientific principles are found in administration. Administrators are acknowledged as experts in their field of work if they were to study how to implement these administrative principles. In 1938, Chester I. Barnard published The Functions of the Executive which was substantially influenced by Herbert A. Simon's writing. So was the book titled Elements of Public Administration which was published in 1930 with Fritz Morstein Marx as the editor. This book questioned the assumption of politicsadministration dichotomy. John Merriman Gaus, in 1950, even delivered a statement that public administration theory means political theory as well. In 1946 and 1947, an article and book written by Robert A. Dahl, Simon and Waldo was published regarding the concept from the principles of public administration. This period is known as a challenge to the dichotomy created in the previous paradigm which had occurred between 1938 to 1950 .

The following period, from 1947 to 1950, is considered by Henry as a reaction to that challenge. During this period, Simon proposed an alternative to the old public administration paradigm. In this new paradigm, scholars mentioned that there is a development of pure science (see Henry, 1975:380). The paradigm of administration principles is such a complex development stage of administration. This result is due to none other than the dichotomy of politics-administration. A number of significant issues in this second paradigm is the application of scientific principles within the scope of public administration, hence placing public administration as a discipline which implements value-free science as intended by Simon and Leonard White.

As part of the development of administrative science, it is interesting to review the ideas of Luther Gulick and Lyndall Urwick, through their work which was published in papers on administrative science in 1937. They introduced seven principles of administration, namely: (1) 
planning; (2) organizing; (3) staffing; (4) directing; (5) coordinating; (6) reporting; and (7) budgeting. These seven principles became infamous with the acronym POSDCORB. According to Gulick and Urwick, these principles can be applied to almost all organizations by emphasizing the aspect of efficiency as the objective of administrative science (see, Milakovich and Gordon, 2013:40; Simon, 1947).

During the period of 1930 to early 1940, public administration is favored because it contains managerial knowledge much needed by the government and industrial sector. Its main focus was on administration principles which can be accepted by various sectors, and thus the locus of public administration was not a topic of debate at the time as administration principles were implemented in general.

The Simon-Waldo debate (Riccuci, 2010:9-15) on values in public administration and Waldo's acknowledgement to Simon's contribution in public administration that objectivity is necessary in certain matters had far-reaching impact on the development of public administration.

\section{Paradigm III: Public Administration as Political Science, 1950-1970.}

The writings on public administration published during this period identified public administration to be a synonym of political science. As Waldo had written in welcoming public administration as political science, "... We are now hardly welcome in the house of our youth". (Waldo in Henry, 1975:382)

Even more interesting is a survey conducted in 1972 to 5 (five) of the most leading political science journal in the time period of 1960-1970 which asserted that only $4 \%$ of all the writings they received were categorized as "political bureaucracy", as one of the 15 categories directly related to public administration.

During this third phase, public administration once again became a part of political science. Government bureaucracy became the locus of analysis albeit a focus of study had to be formulated to avoid similarity with political science. In 1962, public administration was no longer included as a sub-field of political science in the American Political Science Association Committee on Political Science as a Discipline report (Henry, 1975:381). There are two novel developments that are noteworthy in this period, i.e.: firstly, the growth in the use of case study which is epistemological; secondly, the growth of comparative study and development administration as one of the parts of public/ state administration (see Thoha, 2008:28).

\section{Paradigm IV: Public Administration as Administrative Science, 1956-1970.}

In this fourth stage, public administration developed an alternative to advance this scientific discipline. Its development process put more emphasis on focus rather than locus, as was the case in point during the second phase. In this phase, organization theory became one of the focus of public administration, as conveyed by Keith M. Henderson, “...among others, argued in the mid-1960s that organization theory was, or should be, the overarching focus of publicadministration" (Henry, 1975:382).

It is during this very stage that research interest on organizational development with the framework of public administration began to grow. This argument subsequently received criticism, particularly regarding the terminology of public, between state and private, as the definition of public is always connotative to public interest and public relation. Hence, a paradigm that can push the focus and locus of study was in immediate need to be found (Henry, 1975:383).

\section{Paradigm V: Public Administration as Public Administration, 1970-?}

There are several points in this phase: first, public administration has focused itself on 
organizational theory specifically organizational behavior and decision making; second, social factors in underdeveloped countries became its locus; third, scholars focus their interest in policy study, political economy, policy analysis and policy making process, policy outputs as the linkage connecting the focus and locus of public administration (Henry, 1975:383).

\section{Does Public Administration Have a Paradigm?}

Observing the paradigm presented by Nicholas Henry and comparing it to Kuhn's notion on paradigm, then it can be concluded that public administration has no paradigm. A number of reasons why public administration has no paradigm are as follows (Riccuci, 2010:2130) consist of: (1) There is no consensus among public administration scholars in determining what paradigm to use within a certain period of time (based on Thomas Kuhn's pattern); (2) Public administration is an applied field of science. The task of public administration will constantly be concerned around the practical world and applicative means to solve real world issues that are highly political, fragmented, and impermanent (Rainey, 1994); (3) Public administration is established by borrowing theories and approaches of other sciences, leading it to possess a multidisciplinary scientific character.

Riccuci's work titled Public Administration: Traditions of Inquiry Philosophies of Knowledge mentions that various scholars have differing perspectives and approaches in studying public administration. This is why the paradigm presented by Nicholas Henry illustrates that one paradigm has a different belief to another yet they remain connected. There are also occasions in which criticism is aimed towards an opposing paradigm but it does not break or destroy the former paradigm. This means that every paradigm continues to move on although it is discontinued by other paradigms (Riccuci, 2010:46)

\section{Intellectual Crisis}

Intellectual crisis in public administration does not refer to its lack of findings, achievements, and development as a scientific entity. Intellectual crisis is an illustration for the disputes among scholars regarding basis of ontology, epistemology, and methodology in public administration. This is undoubtedly inseparable from its initial origin which had sparked debates among social scientists especially scholars of public administration. The lack of single paradigm as a joint reference for public administration scholars is indeed unavoidable bearing in mind the theoreticalconceptual construction it is founded on is influenced by other scientific disciplines such as politics, management, sociology, etc., thus resulting in the validity and legitimacy of public administration to be constantly challenged (Haque, 1996:512)

In this section, similarity in the discussion materials with previous crises is unavoidable; this is due to there being references and concepts that are alike. However, in order to avoid various reiterations, this section will be focused on the debated value construction aspect. As a reference for the intellectual crisis discussion, academic concepts written by Vincent Ostrom in The Intellectual Crisis in American Public Administration and Shamsul Haque in The Intellectual Crisis in Public Administration in The Current Epoch of Privatization will be much elaborated upon in the following passages.

Vincent Ostrom said that public administration is experiencing confidence crisis due to its loss of identity caused by the failure in understanding the position of public administration's subject matter including how its methodology works, particularly its theoretical basis. Vincent Ostrom through his efforts insisted that all parties seek alternative means in managing public enterprises. He considers public administration to be overly politic minded resulting in its loosing its essence due to being too bureaucratic and elitist. The 
public administration developing at the time, according to Ostrom, was no longer suitable to their needs. Ostrom offered a solution with his theory of democratic administration which is meant as a collective action theory originating from contemporary political economy that is better known as public choice. Three things he suggested be adopted from political economy are as follows: (1) a mindset which accepts that administration management is not a given requirement, because there are options to provide the best solution; (2) can critically provide more perspective to the bureaucracy; and (3) language and conceptual perspectives are necessary in order to realize democratic alternatives (Ostrom in Buchanan, 1974)

In other words, Ostrom argued that public administration should prioritize the public. The use of the "public choice" concept is an analogy to "market", wherein public service is encouraged to be competitive although there is the consequence of privatization. This very idea also contributed in establishing "New Public Management" in which its foundation is that public service must be enhanced for the sake of the public and that state administration should be run similar to the business sector.

This idea garnered much support from many other scholars such as David Osborne and Ted Gaebler who proposed the concept of "reinventing government". Osborne and Gaebler mentioned that bureaucracy only measures and controls input rather than outcome, it is naturally expected that it should refer to a business model which focuses on the outcome (Osborne \& Gaebler, 1992).

Nevertheless, Vincent Ostrom's conception received strong criticism from $\mathrm{M}$. Shamsul Haque through his article titled "The Intellectual Crisis in Public Administration in the Current Epoch of Privatization" which was published in 1996. In the article, Shamsul Haque criticized public administration which became imbued with private values. This privatization not only had an impact in changing the natural form, venue and domain of public service, but also on the credibility of norms and trust in public administration.

Through his publication, Shamsul Haque attempted to criticize the practice of public administration which is currently choke-full of private values in the public sector. This is why Shamsul Haque saw that intellectual crisis has intensely changed into a privatization movement the world over. This had not only influenced the scope and domain of public service but it had influenced the credibility, norm and trust in public administration as well. The privatization ideology has demeaned the legitimacy, ethics, and morale of the public service and thereby created a serious intellectual crisis in public administration as a field of study (Haque, 1996:512-513).

The influence of privatization has changed the natural form, venue, and domain of public service practices in many countries, and it has also influenced the confidence, norm, and academic credibility of public administration (Haque, 1996:512). This means that the thoughts of public administration scholars have been influenced by values of privatization when speaking of public service. Haque (1996:513) stated "Privatization ideology has disparaged the legitimacy, ethics, and morale of the public service and thereby created serious intellectual crisis in public administration as a field of study". Privatization ideology has become the central point of market, and it has become a point of relation/support in collaborations undertaken by businesspeople, the elites and political leaders. When this influence has reached the minds of the elites and political leaders, then it is only natural that the state policies made will be based on values and ideology of the market (privatization).

The crisis occurring in public administration is unlike the intellectual crisis of the past which was debated and resolved within academic circles, the root of the current crisis lies in the practical field of public service, 
public opinion, and public attitude which have been affected by the values and rhetoric of privatization.

Shamsul Haque divided intellectual crisis into three categories: firstly, credibility crisis; secondly, normative crisis; and thirdly, trust crisis. The argument of each of the above crisis is presented below.

Firstly, Credibility Crisis. Reflecting on the major cutback of public sector workforce in England (Dunsire, 1991) and the US (Gore, 1993) which led to the declining number of public administration graduates requested in the government sector, the privatization movement caused a decline in the scope of public service, decrease in the rate of public sector recruitment, and subsequently a drop in the demand for education in public administration. In addition, it has created a negative image of public service, induced reluctance to study public administration, and reduced demand for this study. it is obviously visible that privatization brought about tremendous challenges to public administration. Shamsul Haque saw this as an impairment of public administration's legitimacy and credibility as an academic field (Haque, 1996:515).

Secondly, Normative Crisis. Ethical standards in a democratic society such as public interest, equality, accountability, responsiveness, representation should be the academic norm in public administration. However, the fact is that such values have been changed to pro-market, individual interest, utilitarian, productivity, and efficiency. These various values in the perspective of science are very much influenced by the emergence of New Public Management (NPM), a paradigm which accentuates criteria of economy and efficiency (Haque, 1996:516). Privatization has changed the prevailing norms in public administration into becoming private/ market norms, specifically in policy study and policy analysis. The theoretical framework used in policy study and policy analysis are the same as the theoretical framework of privatization which is the theory of public choice. The implication is that private norms such as individualism, utilitarianism, productiveness, and efficiency replace public norms such as accountability, representation, justice, and responsiveness (Haque, 1996 :518)

Thirdly, Trust Crisis. The change of democratic values and the progressively strong privatization as an ideology have reduced trust in public administration. The uncertainty of its graduates securing employment, the hindered motivation of the scholars (Farazmand, 1989) and their concern (Ventriss, 1989) for their professional future caused by the rejection of credibility in the field of public administration (in Haque, 1996:519), these various arguments can be comprehended as an academic (epistemology-paradigm) and practical change which has altered the norm of publicness to become closer to market values. In response to this, a systematic effort to question the validity of the privatization argument is necessary, a thorough criticism is needed to reestablish public administration norms favoring the public interest.

The concept of private values replacing public values is also found in the writing of Osborne and Gaeblers titled "Reinventing Government", wherein business approaches and private values were used in managing the public sector. Furthermore, this concept considers the citizens as customers. In response to the privatization phenomenon with its market value assessment which in the literature is well-known as New Public Management, Reinventing Government, Denhardt and Denhardt (2000:549-557) attempt to return public norms into the public sector. They came up with an alternative model called New Public Service. The essence of this model is that

“...public administration should focus on their responsibility to serve and empower citizens as they manage public organizations and implement public policy" 
By placing citizens as the core at the forefront, they will no longer be considered as customers, but "citizens as citizens", thus the main focus of the government is by building public institutions bearing integrity and responsiveness, not by placing emphasis on steering or rowing the proverbial governmental boat.

\section{Implications of the Public Administration Crises}

Various intellectual debates pertaining to public administration have brought about empirical implications to many things. The adoption of privatization becomes an example of the scientific complexity in public administration. Additionally, the dynamics of public administration in Indonesian universities serve as an interesting example regarding the implications of the shift in locusfocus and paradigm in public administration. Following the change of political system from authoritarian to a democratic one, there is an interesting academic discourse particularly in viewing and responding to the locus and focus of a certain scientific discipline. In the context of public administration as a scientific discipline, there is a shift in the use of the nomenclature state administration to public administration, even in the case of Gadjah Mada University, the Department of State Administration was subsequently changed to the Department of Public Policy and Management.

In several campuses studying administrative science, obvious differences can be observed in the nomenclature for public administration. Beginning with the nomenclature of state administration which emphasizes on government administration as the locus. The term state administration in Indonesia became known concurrently with the approach used in managing the country which laid emphasis on power orientation. Power orientation originating from the state made all the efforts in conducting administration to become state driven (sarwa negara). Currently, the paradigm has changed, the state driven approach has changed into the community driven (sarwa masyarakat) approach (Thoha, 2008:67).

Warsito Utamo, professor of public administration at Gadjah Mada University also highlighted the importance of a new perspective in observing the shift in the meaning of public as state into public as society (not mere nomenclature), wherein the approach is no longer to the community or customer oriented or customer approach. This is in accordance to the government's demand for change, in which emphasis was initially put on "authority", into governance which emphasizes compatibility among actors: state, private, and civil society (Warsito, 2009:8)

Agus Dwiyanto in his inaugural speech for professorship at Gadjah Mada University proposed an alternative idea to broaden the locus of public administration, so that it is no longer limited to government institutions, but covers all institutions with a core mission of actualizing publicness. This means that the concept of public in public administration is no longer defined as an institution but more as orientation and values of publicness. Upon observation of this change, Agus Dwiyanto subsequently suggested that public administration study become governance study. Public bureaucracy as a venue for practices and theories of public administration is no longer suitable as there are more and more public interests and issues that are in fact being addressed by nongovernment institutions (2007:106-118). If we examine this change, it is obvious that change in the social-political system of a country demands change in their scientific point of view as well so that it can contribute in resolving the various developing phenomenon. In other words, it is necessary to have a new paradigm that is appropriate to the development (change) replacing the dominant paradigm previously employed. 


\section{Conclusion}

The first intellectual debate which emerged concerned the identity of public administration as a discipline. This refers to the concept of politics-administration dichotomy (Wilson,1887; Frank J Goodnow, 1900;LeonardDWhite,1927)which emphasized the systematical efforts in dividing the scope of politics-administration. The academic zeal encouraged in this period is in finding new approaches to assist the government in public services movement and establish government bureaucracy as the locus of study. The subsequent intellectual debate pertained to principles of methodology/approach utilized in public administration. As a scientific entity, the suggestion to apply scientific principles is surely unavoidable. The emergence of administration principles which became the basis for public administration scholars was consequently observed to occur. Yet, in reality, there were numerous challenges especially in the aspect of administration as a value free science which could not be universally accepted.

The following period of debates were more regarding the issue of which theory-paradigm should be used bearing in mind that the public administration discipline was constructed to be inseparable from other sciences such as politics, management, sociology, etc. Although in the period of 1950-1970 there were still vehement debates pertaining to the identity of public administration as its own scientific discipline or as a sub-field of political science, public administration acquired its scientific identity in the period of 1956-1970, i.e. public administration as administrative science. For the following years, 1970-current, it is generally accepted that public administration be regarded as public administration.

Shamsul Haque's idea is also no less interesting, wherein he asserts that public administration norms have changed from democratic values (equality, representation, public interest, citizenry) into market values (individual interest, utilitarian, productiveness, efficiency). This change occurred as a consequence of the adoption of privatization into public administration.

The differing ideas and arguments delivered throughout every debate regarding public administration have implications on the heterogeneity of the field of public administration. The search for the meaning of "publicness" which still continues, the shift from one paradigm to another, as well as the shift of locus-focus, all of them show the constant endeavor undertaken by public administration to demonstrate its identity. The identity that separates itself from the shadows of political science, although the effort of truly being detached from it seems to be a matter of immense difficulty, keeping in mind that the locus and focus of public administration are very much affected by continually developing social-political influences. Additionally, various shifts in locus and focus seems to have empirical implications, especially in the scientific scope of public administration. The reality transpiring in the world is undoubtedly dynamic. Public administration has to adapt to occurring changes and anomalies, and provide contributions beneficial to the theoretical and empirical development of public administration.

\section{References}

Buchanan, B. (1974). “The Intellectual Crisis in American Public Adminitration by Vincent Ostrom". Public Choice Volume 19 (Fall). Springer.

Dendhardt, R.B. and Dendhardt, J. Vinzant. (2000). The New Public Service, Public Administration Review, 60(6), pp. 549559.

Goodnow, J. Frank. (1900). Politics and administration, A Study in Government, The Macmilan Company New York, USA.

Haque, M.Shamsul. (1996). The Intelectual Crisis in Public Administration in The Current 
Epoch of Privatization. Administration \& Society, 27(4), pp. 510-536.

Henry, Nicholas. (1975). Paradigm of Public Administration. Public Administration Review, 35(4), pp. 378-386.

Hiba Khodr (2005). Public Administration and Political Science: An Historical Analysis of the Relation Between the Two Academic Disciplines. Dissertation, Collage of Social Science, The Florida State University Libraries.

Hummel, P. Ralph. (1989). The Crisis in Public Administration Theory. Dialogue, 11(4), pp. 1-4.

Inaugural Speech for Professorship (2007). "Dari Administrasi Negara ke Administrasi Publik". Yogyakarta: Gadjah Mada University Press.

Kirwan, K. Aiken. (1977). The Crisis of Identity in the Study of Public Administration: Woodrow Wilson. Polity, 9(3), pp. 321-343.

Kuhn, T., S. (1962). The Structure of Scientific Revolutions. Chicago: University of Chicago Press.

Milakovich, E, Michael \& Gordon, J, George. (2013). Publik Administration in Amerika. Wadsworth, Boston, USA: Eleventh Edition
Osborne, David. And Gaebler, T. (1992). Reinventing Government. Reading, MA: Addison-Wesley.

Ostrom, V. (1973). The Intellectual Crisis in American Public Administration. Second Edition, University of Alabama Press.

Pesch, Udo. (2005). The Predicaments of Publicness: An Inquiry into The Conceptual Ambiguity of Public Administration. Eburon Academic Publishers.

Riccuci, N.M. (2010). Public Administration: Traditions of Inquiry and Philosophies of Knowledge. Washington, D.C. USA: Georgetown University Press.

Ritzer, George. (2013). Sosiologi Ilmu Pengetahuan Berparadigma Ganda. Jakarta: Raja Grafindo Persada.

Thoha, Miftah ( 2008). Ilmu Administrasi Publik Kontemporer. Jakarta: Kencana Prenada Media Group.

Utomo, Warsito. (2009). Administrasi Publik Baru Indonesia: Perubahan Paradigma dari Admnistrasi Negara ke Administrasi Publik. Yogyakarta: Pustaka Pelajar.

Wilson, Woodrow. (1887). The Study of Administration. Political Science Quarterly, 2(2), pp. 197-222. 